\title{
Impact of Free Radicals on the Electrostatic Charging Tendency of Transformer Oils
}

\author{
M. Talhi ${ }^{\mathrm{a}}$, I. Fofana ${ }^{\mathrm{b} *}$ and S. Flazi ${ }^{\mathrm{c}}$ \\ ${ }^{a}$ Institut de maintenance et de sécurité Industrielle, Université d'Oran 2 (Algérie) \\ aLaboratoire de Génie Electrique d'Oran (LGEO), Université des Sciences et de la Technologie d'Oran \\ Mohamed Boudiaf \\ ${ }^{b}$ Research Chair on Aging Power Network Infrastructure (ViAHT), Université du Québec à Chicoutimi (UQAC), \\ Quebec, Canada \\ 'Université des Sciences et de la Technologie d'Oran Mohamed Boudiaf \\ *Corresponding author: ifofana@uqac.ca; tel : +1 418545 5011, p. 2514 Fax: 14185455012.
}

\begin{abstract}
In this contribution, the influence of free radicals concentration on the Electrostatic Charging Tendency (ECT) of aged mineral oils is reported. A free radical reagent, 2,2 diphenyl-1-picrylhydrazyl (DPPH), is used to assess the relative concentration of free radicals. Prior to the ECT measurement, the oil samples were subjected to various stresses (corona discharges, multiple arcs or local overheating). Different ASTM standards were considered to assess the physicochemical properties before and after stress applications. It is found that free radicals affect the ECT. The theoretical premises that, free radicals may contribute to the ECT, is experimentally confirmed under laboratory conditions. The reason why this information is important is that ECT can significantly affect partial discharge inception in in-service transformers.
\end{abstract}

Index Terms : Power transformer, mineral oil, free radicals, ECT.

\section{INTRODUCTION}

A pure insulating liquid, by virtue of its chemical properties, should not ionize to any significant amount, but charge generation is seen in liquid-filled equipment [1]. Electrostatic charge generation occurs in insulating liquid filled systems because of friction with solid components [2-6]. This friction only occurs when there is relative motion between oil and the surface of the solid material. Many investigators have studied the electrostatic charge generation of insulating liquids. Although the subject has been studied in detail, the experimental works have not resulted in a single coherent theory [5-22]. The magnitude of charge generated depends on many interrelated factors, including the fluid physicochemical properties and the intrinsic properties and surface condition (geometry, roughness, porosity, etc.) of the cellulose paper as well as some external parameters such as the fluid's velocity and temperature. In service conditions, oil aged under various stresses. The concomitant oxidation by-products (peroxide gas, water, soluble acids, low molecular weight acids, fatty acids, water, alcohols, metallic soap, aldehydes, ketones, lacquers, sludges of asphaltene) which change the physicochemical makeup of the oil [23] are also contributing factors.
Since the streaming electrification is directly related to the conductivity of the fluid [24, 25] any charged particles must contribute to the phenomena. Higher conductivity means that the charge generated may increase the likelihood of discharge.

From the chemical view point, the process of decomposition of insulating oils under different stresses (electrical, chemical and thermal) begins with the breaking of covalent bonds in unstable hydrocarbon molecules [1-3]. As long as these hydrocarbon chains are not broken, the formation of decomposition products is impossible [26, 27]. The energy sources capable of breaking a covalent bond composed of a pair of electrons are:

- The electromagnetic field that triggers the injection of free electrons into the liquid.

- Heat generated by the active part of the transformer.

- The aggressiveness of dissolved oxygen (enhanced by the catalytic effect of copper), acids and other aging by-products for the decomposition process.

The decomposition byproducts such as gases, free radicals, ionized molecules, sludges and waxes accelerate the ageing of oil.

At the XIX Symposium on Insulating Materials held in Japan in 1986 [28], J. Tanaka concluded that free radicals play a critical role in the degradation process of all dielectric materials. Among the factors which influence the generation of the free radicals [29] :

- The source of energy necessary for the decomposition process.

- The amount of dissolved, low-binding impurities found to be precursors

- The exposure of the oil to ultraviolet light [30].

- The field resulting from the application of a high voltage, which increases the probability of reactions between the free radicals themselves because of their paramagnetic nature.

The aim of this contribution is to investigate the influential effect of free radicals onto the Electrostatic Charging Tendency (ECT) of aged oils.

\section{EXPERIMENTAL PROCEDURE}

A rotating disk system designed in laboratory was covered on both sides with paper. This system has long time ago been adopted by CIGRE for international 
comparative measurements [31, 32]. Many researchers employed the disc in rotation to study the ECT of transformer oils [7, 8, 12, 33-38]. A $40 \mathrm{~mm}$ diameter disk was used in these experiments. The whole system was placed in a Faraday cage (Fig. 1). The disc rotation is controlled by a DC motor. The speed of the disc was varied between 300 and $600 \mathrm{rpm}$. The streaming electrification current was recorded via an Excelinx data acquisition system developed by Keithley and measured with a programmable electrometer (Keithley 6514). Cellulose and aramid (a synthetic polyamide) based papers (1 and $3 \mathrm{~mm}$ ) were used to cover the disc. These paper samples were dried under vacuum in an oven at 100 ${ }^{\circ} \mathrm{C}$ during 48 hours and impregnated with unaged dried and degassed mineral oil. The drying and degassing process lasted 24 hours.

The ECT was studied with a naphtenic-based mineral oil artificially aged in laboratory conditions. Copper Strip $\left(15 \mathrm{~cm}^{2}\right.$ in $400 \mathrm{ml}$ of oil) was used as catalyst according to the ASTM D 1934-95 standard [39]. The reduction in the interfacial tension (IFT) served as parameter to monitor the degradation rate.

For each oil sample, the streaming electrification current was measured at different rotational speeds. For each speed, the current was recorded at a sampling rate of 195 samples per minute.

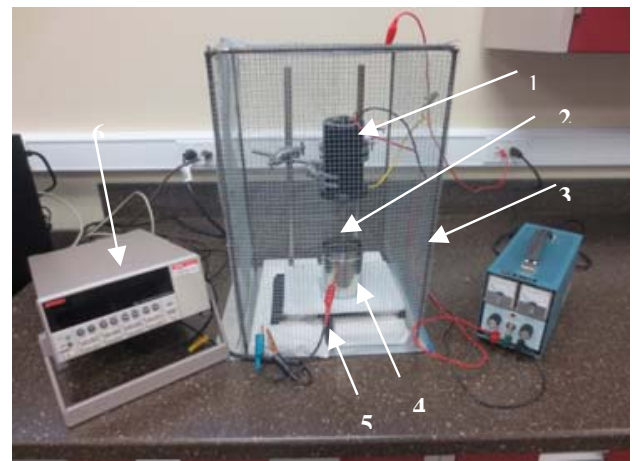

Fig. 1. (1) DC motor; (2) aluminum mandrel; (3) Faraday cage; (4) measuring container containing oil; (5) coaxial cable; (6) Electrometer.

Before streaming electrification current measurement, the oil samples were subjected to various stresses.

\subsection{Stress 1: electrical discharge}

A Merell-based test cell type, defined in the ASTM Test Method D 6180 [40], was considered. The free electrons are generated by a cylindrical copper electrode of $15 \mathrm{~mm}$ (0.6 inches) in diameter and $10 \mathrm{~mm}$ long, sealed in a 500 $\mathrm{ml}$ Erlenmeyer glass. The electrode was placed at the center of the discharge cell and suspended above the oil (Fig. 2). Before voltage application, the discharge cell is degassed under vacuum down to 1 Torr, i.e. $133 \mathrm{~Pa} .10$ $\mathrm{kV}$ voltage is then applied to the oil sample for 5 hours. The pressure is measured every hour to monitor gas generation inside the test cell.

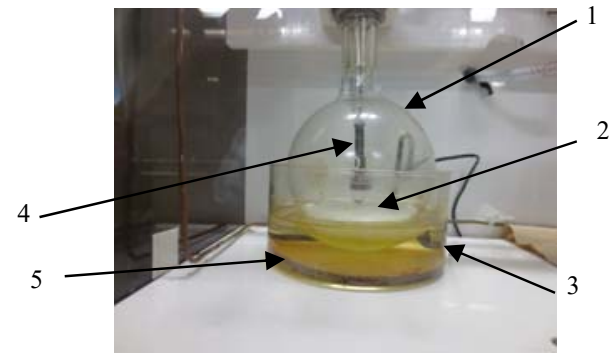

Fig. 2. Overview of the test method for stability of oil under electrical discharges according to the ASTM D 6180. (1) Erlenmeyer; (2) foam of oil after voltage application; (3) Glassware containing salted water ; (4) High voltage electrode; (5) Low voltage electrode connected to ground.

\subsection{Stress 2: electrical breakdown}

50 breakdown tests were subjected to oil sample according to ASTM 877 [41]. An overview of the test system is presented in Figure 3. This type of arc is not a long burning arc, but rather a spark in the oil. Therefore, 50 arcs are necessary for oil degradation [42].

\subsection{Stress 3: local overheating}

A laboratory-designed setup was used to simulate a local overheating in the oil samples. The setup consisted of a Borosilicate-glass vessel and a Teflon cover with clamps to hold the heating wire. The heating wire was made of constantan (selected for its stable resistivity in a wide range of temperatures). The local overheating was applied for a total duration of $30 \mathrm{~min}$. The temperature, measured with a NiCrNi temperature sensor, was controlled to approximately $250{ }^{\circ} \mathrm{C}$. The heating current was supplied by a high current (low voltage output) power transformer, while the temperature of the wire was regulated by the output current red on an ammeter connected to the secondary circuit. This test setup allows simulating local overheating of the liquid up to $500{ }^{\circ} \mathrm{C}$ [43] (Fig. 4).

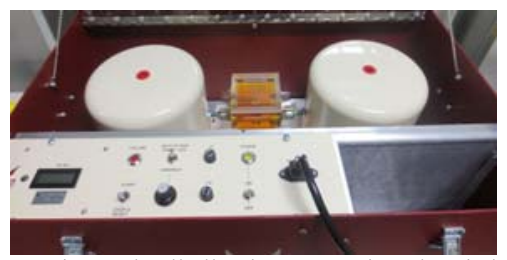

Fig. 3. The experimental cell allowing generating electric breakdown in oil according to ASTM D877.

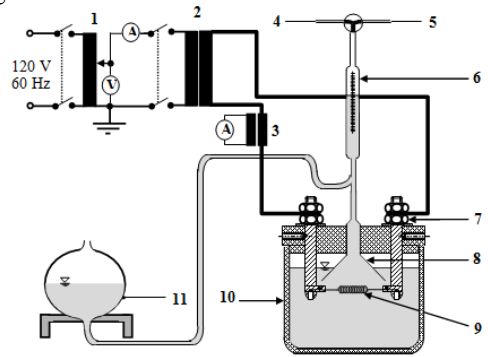

Fig. 4. Experimental setup sketching the local overheating of the insulating fluid samples. (1) regulator; (2) Transformer; (3) current transformer; (4-5) Measuring pipette; (7) Clamps; (8) Aluminum funnel; (9) Heating elements; (10) Test vessel; (11) Equalising vessel. 


\subsection{Combined stresses}

In real life conditions, oil are stressed from various sources. Therefore, the oil samples were also submitted to combination of some stresses as illustrated in Tables 1 and 2 .

To monitor the quality of the oil samples, various parameters were determined before and after stress application(s), namely the moisture content by Karl Fisher titration [44], turbidity in oil by a ratioturbidimeter [45], the interfacial tension [46], the dissolved decay products (DDP) by UV/Vis spectrophotometer [47] and the relative amount of free radicals [48].

\section{RESULTS AND DISCUSSIONS}

\subsection{Oil samples quality assessment}

Tables 1 and 2 summarize the results obtained from the following four diagnostic techniques: interfacial tension, dissolved decay products (DDP), turbidity and moisture content. These properties were assessed before and after stress application(s). The purpose of these measurements was to evaluate the impact of secondary chemical reactions between radicals generated from the oil's degradation.

Table 1. Properties of the artificially aged mineral oil (samples aged with Aramid papers) before and after stress applications.

\begin{tabular}{|c|c|c|c|c|}
\hline \multicolumn{5}{|c|}{ Mineral oil (120h) } \\
\hline & $\begin{array}{l}\text { Interfacial } \\
\text { tension } \\
\text { (dynes/cm) }\end{array}$ & $\begin{array}{l}\text { Moisture } \\
\text { content } \\
(\mathrm{ppm})\end{array}$ & $\begin{array}{l}\text { DDP } \\
\text { (a.u.) }\end{array}$ & $\begin{array}{l}\text { Turbidity } \\
\text { (NTU) }\end{array}$ \\
\hline Without stress & 31.80 & 20.2 & 85.63 & 0.872 \\
\hline Stress 1 & 28.05 & 23.4 & 90.57 & 2.15 \\
\hline Stress 2 & 30.54 & 22.3 & 85.70 & 1.66 \\
\hline Stress 3 & 25.60 & 25.8 & 170.5 & 3.01 \\
\hline Stress3+Stress 2 & 23.18 & 27.4 & 17569 & 3.20 \\
\hline \multicolumn{5}{|c|}{ Mineral oil (192 h) } \\
\hline & $\begin{array}{l}\text { Interfacial } \\
\text { tension } \\
(\text { dynes/cm) }\end{array}$ & $\begin{array}{l}\text { Moisture } \\
\text { content } \\
(\mathrm{ppm})\end{array}$ & $\begin{array}{l}\text { DDP } \\
\text { (u.a.) }\end{array}$ & $\begin{array}{l}\text { Turbidity } \\
\text { (NTU) }\end{array}$ \\
\hline Without stress & 29.29 & 26 & 98.22 & 2.09 \\
\hline Stress 1 & 28.05 & 31.5 & 144.5 & 2.01 \\
\hline Stress 2 & 24.38 & 28.7 & 142.2 & 2.20 \\
\hline Stress 3 & 20.81 & 36.1 & 185.3 & 3.90 \\
\hline Stress3+Stress 2 & 19.05 & 39 & 191.2 & 4.10 \\
\hline \multicolumn{5}{|c|}{ Mineral oil (240 h) } \\
\hline & $\begin{array}{l}\text { Interfacial } \\
\text { tension } \\
\text { (dynes/cm) }\end{array}$ & $\begin{array}{l}\text { Moisture } \\
\text { content } \\
(\mathrm{ppm})\end{array}$ & $\begin{array}{l}\text { DDP } \\
\text { (a.u.) }\end{array}$ & $\begin{array}{l}\text { Turbidity } \\
\text { (NTU) }\end{array}$ \\
\hline Without stress & 23.18 & 38.4 & 146.1 & 2.49 \\
\hline Stress 1 & 17.90 & 42.8 & 187.5 & 4.06 \\
\hline Stress 2 & 21.99 & 41.8 & 148.5 & 3.08 \\
\hline Stress 3 & - & - & - & - \\
\hline Stress3+Stress 2 & - & - & - & - \\
\hline \multicolumn{5}{|c|}{ Mineral oil (624 h) } \\
\hline & $\begin{array}{l}\text { Interfacial } \\
\text { tension } \\
(\text { dynes/cm) }\end{array}$ & $\begin{array}{l}\text { Moisture } \\
\text { content } \\
(\mathrm{ppm})\end{array}$ & $\begin{array}{l}\text { DDP } \\
\text { ( a.u.) }\end{array}$ & $\begin{array}{l}\text { Turbidity } \\
\text { (NTU) }\end{array}$ \\
\hline Without stress & 15.06 & 72.9 & 355.6 & 4.08 \\
\hline Stress 1 & 15.62 & 90.1 & 393.1 & 12.65 \\
\hline Stress 2 & 15.62 & 79.5 & 356.5 & 5.98 \\
\hline Stress 3 & - & - & - & - \\
\hline Stress3+Stress 2 & - & - & - & - \\
\hline
\end{tabular}

Table 2. Properties of the artificially aged mineral oil (samples aged with cellulose papers) before and after stress applications.

\begin{tabular}{|c|c|c|c|c|}
\hline \multicolumn{5}{|c|}{ Mineral oil $(0 \mathrm{~h})$} \\
\hline & $\begin{array}{l}\text { Interfacial } \\
\text { tension } \\
(\text { dynes } / \mathrm{cm})\end{array}$ & $\begin{array}{l}\text { Moisture } \\
\text { content } \\
\text { (ppm) }\end{array}$ & $\begin{array}{l}\text { DDP } \\
\text { (a.u.) }\end{array}$ & $\begin{array}{l}\text { Turbidity } \\
\text { (NTU) }\end{array}$ \\
\hline Without stress & 3838 & 2.4 & 3.38 & 0.728 \\
\hline Stress 1 & 34 & 23.5 & 12.79 & 2.14 \\
\hline Stress 2 & 35 & 17.2 & 8.73 & 1.8 \\
\hline Stress 3 & 32 & 28 & 45.39 & 2.53 \\
\hline Stress3+Stress 2 & 31 & 29.7 & 45.10 & 2.65 \\
\hline \multicolumn{5}{|c|}{ Mineral oil (168 h) } \\
\hline & $\begin{array}{l}\text { Interfacial } \\
\text { tension } \\
(\text { dynes } / \mathrm{cm})\end{array}$ & $\begin{array}{l}\text { Moisture } \\
\text { content } \\
(\mathrm{ppm})\end{array}$ & $\begin{array}{l}\text { DDP } \\
\text { (a.u.) }\end{array}$ & $\begin{array}{l}\text { Turbidity } \\
\text { (NTU) }\end{array}$ \\
\hline Without stress & 31 & 21.7 & 73.38 & 0.895 \\
\hline Stress 1 & 29 & 29.1 & 83.57 & 2.21 \\
\hline Stress 2 & 30 & 26.6 & 74.03 & 1.9 \\
\hline Stress 3 & 26.82 & 32.1 & 178.7 & 3.43 \\
\hline Stress3+Stress 2 & 28.65 & 35.1 & 193.2 & 3.87 \\
\hline \multicolumn{5}{|c|}{ Mineral oil (401 h) } \\
\hline & $\begin{array}{l}\text { Interfacial } \\
\text { tension } \\
\text { (dynes/cm) }\end{array}$ & $\begin{array}{l}\text { Moisture } \\
\text { content } \\
(\mathrm{ppm})\end{array}$ & $\begin{array}{l}\text { DDP } \\
\text { (a.u.) }\end{array}$ & $\begin{array}{l}\text { Turbidity } \\
\text { (NTU) }\end{array}$ \\
\hline Without stress & 26.82 & 32.4 & 325.6 & 0.924 \\
\hline Stress 1 & 23.18 & 38 & - & 2.98 \\
\hline Stress 2 & 25.60 & 37.4 & 326.3 & 1.96 \\
\hline Stress 3 & 20.81 & 40.1 & 330 & 3.7 \\
\hline Stress3+Stress 2 & 25.60 & 43.8 & 329.7 & 3.93 \\
\hline \multicolumn{5}{|c|}{ Mineral oil (435 h) } \\
\hline & $\begin{array}{l}\text { Interfacial } \\
\text { tension } \\
(\text { dynes } / \mathrm{cm})\end{array}$ & $\begin{array}{l}\text { Moisture } \\
\text { content } \\
\text { (ppm) }\end{array}$ & $\begin{array}{l}\text { DDP } \\
\text { (a.u.) }\end{array}$ & $\begin{array}{l}\text { Turbidity } \\
\text { (NTU) }\end{array}$ \\
\hline Without stress & 23.18 & 37.6 & 329.6 & 2.38 \\
\hline Stress 1 & 19.05 & 44.5 & - & 3.90 \\
\hline Stress 2 & 20.81 & 42.2 & 331.6 & 2.68 \\
\hline Stress 3 & 16.19 & 48.4 & 337.8 & 4.81 \\
\hline Stress3+Stress 2 & 20.81 & 49.5 & 335.7 & 4.98 \\
\hline \multicolumn{5}{|c|}{ Mineral oil (477 h) } \\
\hline & $\begin{array}{l}\text { Interfacial } \\
\text { tension } \\
\text { (dynes/cm) }\end{array}$ & $\begin{array}{l}\text { Moisture } \\
\text { content } \\
(\mathrm{ppm})\end{array}$ & $\begin{array}{l}\text { DDP } \\
\text { (a.u.) }\end{array}$ & $\begin{array}{l}\text { Turbidity } \\
\text { (NTU) }\end{array}$ \\
\hline Without stress & 16.53 & 53.6 & - & 3.46 \\
\hline Stress 1 & 16.19 & 55.7 & - & 4.20 \\
\hline Stress 2 & 16.19 & 55.7 & - & 3.70 \\
\hline Stress 3 & 15.06 & 63.8 & - & 4.20 \\
\hline Stress3+Stress 2 & 15.06 & 51.2 & 450 & 5.10 \\
\hline \multicolumn{5}{|c|}{ Mineral oil $(1,800$ h) } \\
\hline & $\begin{array}{l}\text { Interfacial } \\
\text { tension } \\
\text { (dynes/cm) }\end{array}$ & $\begin{array}{l}\text { Moisture } \\
\text { content } \\
(\mathrm{ppm})\end{array}$ & $\begin{array}{l}\text { DDP } \\
\text { (a.u.) }\end{array}$ & $\begin{array}{l}\text { Turbidity } \\
\text { (NTU) }\end{array}$ \\
\hline Without stress & 15.06 & 70.8 & - & 3.70 \\
\hline Stress 1 & 15.06 & 84.5 & 525.4 & 10.5 \\
\hline Stress 2 & 15.62 & 76.4 & 600.7 & 5.86 \\
\hline Stress 3 & - & - & - & - \\
\hline
\end{tabular}

\subsection{Interfacial Tension of the oil samples with aging duration}

The results of the interfacial tension over the aging period (0-2000 hours) are reported in Fig. 5, both for oil impregnated aramid and cellulose papers. The IFT provides an indication of the soluble polar compounds content in the oil. The measurement of the IFT is known to provide a sensitive means of detecting small amounts of soluble polar contaminants and oxidation products. A high value of the Interfacial tension indicates the absence of undesired polar contaminants. Out of Fig. 5, it can be noticed that the IFT decreases with elapsed aging time for oil samples aged with both type of paper up to 1000 hours. Beyond this aging duration, the IFT saturates. However, it is important to note that the IFT may not be very sensitive to detect changes in oil quality [31].

After 500 hours, the IFT decreases below 20 dynes / cm; the quality of the oil is considered very bad at this value [49]. 
Fig. 6 shows a photograph of the catalyst (copper foil) partnered with both solid insulation after aging. The foils aged with oil impregnated cellulose papers depict more deposits indicating more severe degradation. This is because; cellulose degrades more rapidly than aramid paper as shown in Fig. 5.

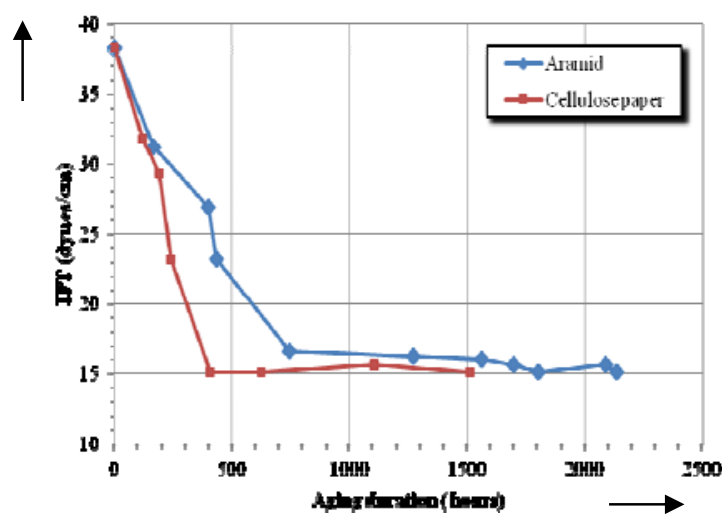

Fig. 5. Evolution of the interfacial tension with elapsed aging time.

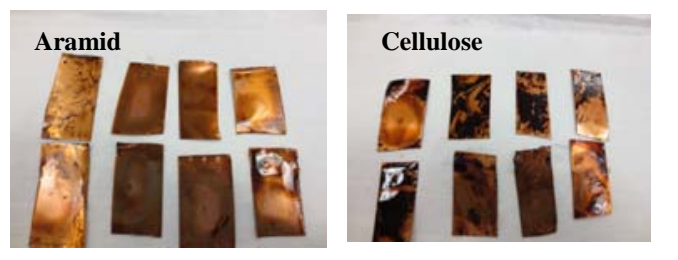

Fig. 6. Photograph of the catalysts partnered with both solid insulation at the end of the aging procedure.

Fig. 7 illustrates the variation of the breakdown voltage as a function of aging duration before stress applications. Clearly, the breakdown voltage of the oil decreases with aging as expected [50-52].

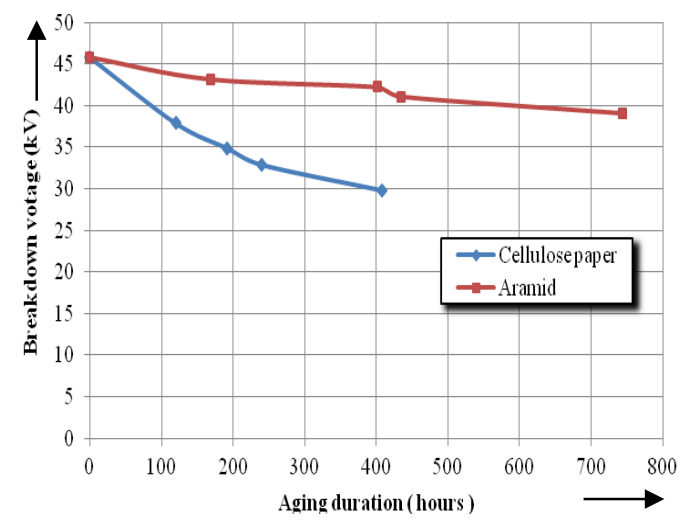

Fig. 7. Variation of the breakdown voltage of the oil (samples aged with either Aramid or cellulose papers) as a function of the aging duration. The measurements were performed at $20^{\circ} \mathrm{C}$.

This can be traced to higher levels of impurities and moisture content in the oil. The results reported in Tables 1 and 2 confirm the presence of these contaminants in the oil after aging.

Fig. 8 represents the average value of the streaming electrification current (in pA) and the IFT as a function of aging duration for a rotational speed of $600 \mathrm{rpm}$ before stress application. The increase in the polar compounds (as assessed by the decrease of the IFT) affects the streaming electrification current.

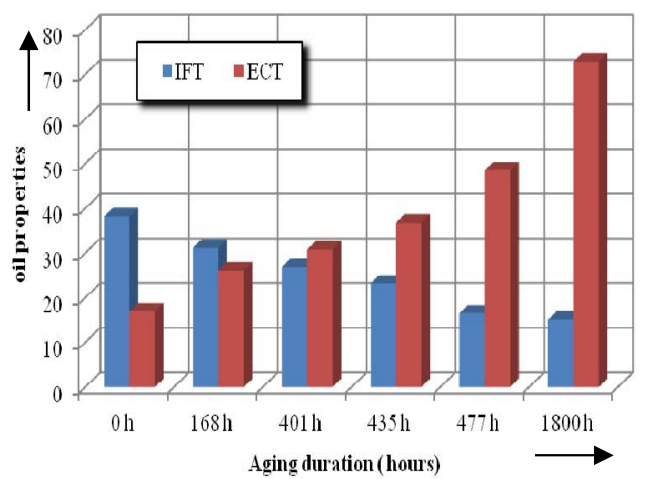

Fig. 8. Average value of the streaming electrification current and Interfacial tension as a function of aging duration. The measurements were performed at $20^{\circ} \mathrm{C}$ with a $4 \mathrm{~cm}$ disc in diameter, covered with a 1 $\mathrm{mm}$ thick aramid paper was used.

\subsection{Impact of electrical stress (stress 1) on the ECT}

The variation of the streaming electrification current after the application of the electrical stress (Stress 1) are summarized in Fig. 9 for different rotational speeds.

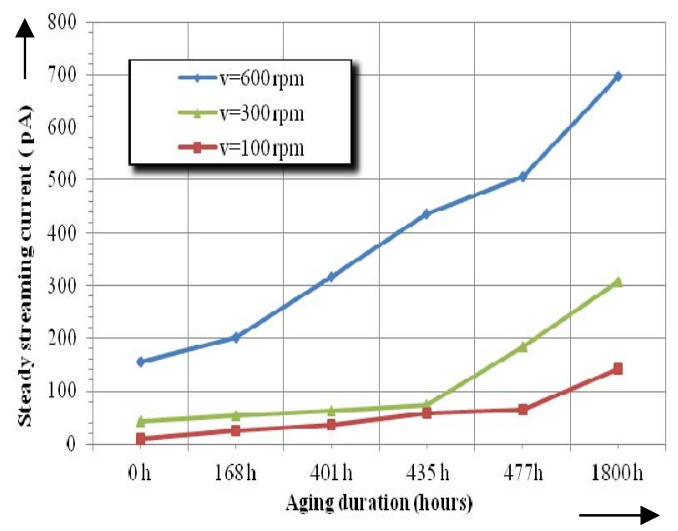

Fig. 9. Average values of the streaming electrification current as a function of aging duration for different rotaional speeds after the application of the electrical stress (Stress 1). A disc of $4 \mathrm{~cm}$ in diameter was covered with $1 \mathrm{~mm}$ thick aramid was used.

It should be emphasized that the streaming electrification current increases with the rotational speed and aging duration. These results confirm observations reported in the literature $[10,33]$. After the application of the electric stress, the rupture of the hydrocarbon chains is possible. Consequently, the conductivity of the oil increases because of the presence of the decomposition byproducts. The ECT or streaming electrification current increases with increasing conductivity [53].

\subsection{Impact of electrical stress (stress 2) on the ECT}

Fig. 10 shows the variation of the streaming electrification current after the application of the electrical stress (stress 2) as a function of the aging duration. 
The application of 50 breakdown tests on the new (unused) or aged oil contributes to the breakage of unstable covalent bonds; thus increase the of charged particles and consequently the ECT. The higher the rotational speed, the higher the ECT is.

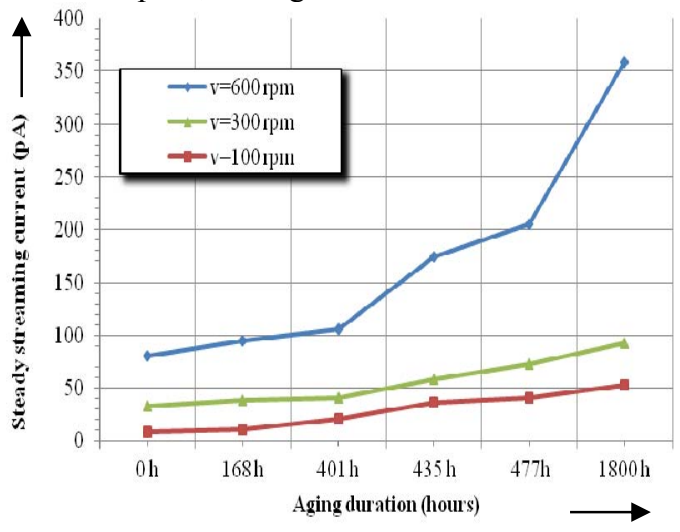

Fig. 10. Average value of the streaming electrification current as a function of the aging duration for different rotational speeds after the application of the electrical stress (Stress 2). A disc of diameter in $4 \mathrm{~cm}$, covered with a $1 \mathrm{~mm}$ thick aramid = was used.

\subsection{Impact of the thermal stress (stress 3) on the ECT}

Fig. 11 summarizes the variation of the streaming electrification current after the application of the electrical stress (stress 3) as a function of the aging duration.

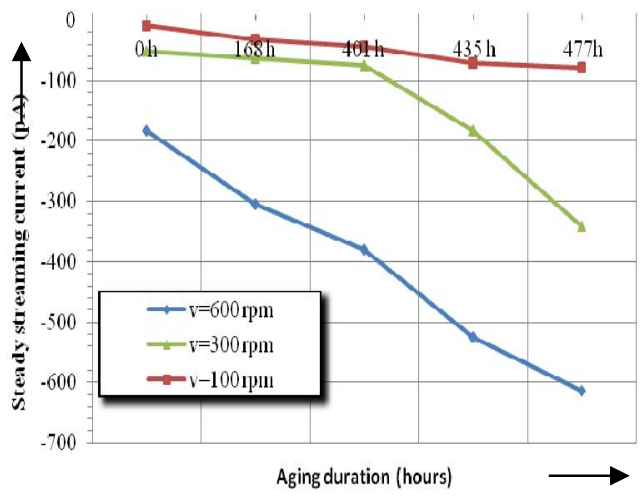

Fig. 11. Average value of the streaming electrification current as a function of the aging duration for different rotational speeds after the application of the local thermal stress (Stress 3). A $4 \mathrm{~cm}$ disc in diameter, covered with $1 \mathrm{~mm}$ thick aramid = was considered

The thermal aging of the oil produces oxidation byproducts. If the oil is strongly oxidized, the static electrification current increases accordingly.

The application of the thermal stress caused of the charge polarity reversal. This polarity reversal phenomenon was also observed after the addition of certain additives in the oil $[2,3]$. The higher the rotational speed, the higher the magnitude of the ECT is.

\subsection{Influence of type of paper on the ECT}

Figures 12, 13 and 14 illustrate the variation of the average electrification current of the oil as a function of the type of paper before and after stress applications. The type of stress acted as parameter.

Clearly, Aramid paper depicts much lower ECT current indicating that the chemical structure of the paper affects the electrification current. Another aspect to consider is that the smoother surface of the aramid compared to that of the cellulose, which might play also play a role in the ECT process.

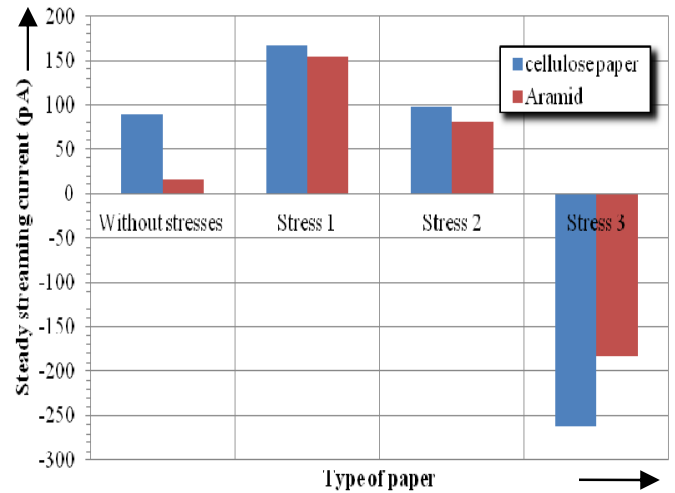

Fig. 12. Average streaming electrification current of the new oil for two type of paper. A $4 \mathrm{~cm}$ disc in diameter and $1 \mathrm{~mm}$ thick $=$ paper was considered. The rotational speed was set to $\mathrm{v}=600 \mathrm{rpm}$ while the Interfacial tension of the oil was 38 dynes $/ \mathrm{cm}$.

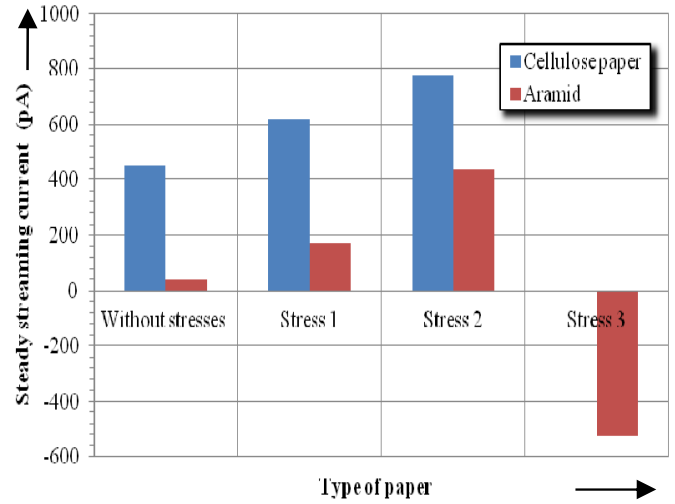

Fig. 13. Average streaming electrification current of the new oil for two type of paper. A $4 \mathrm{~cm}$ disc in diameter and $1 \mathrm{~mm}$ thick = paper was considered. The rotational speed was set to $\mathrm{v}=600 \mathrm{rpm}$ while the Interfacial tension of the oil was 23.18 dynes $/ \mathrm{cm}$.

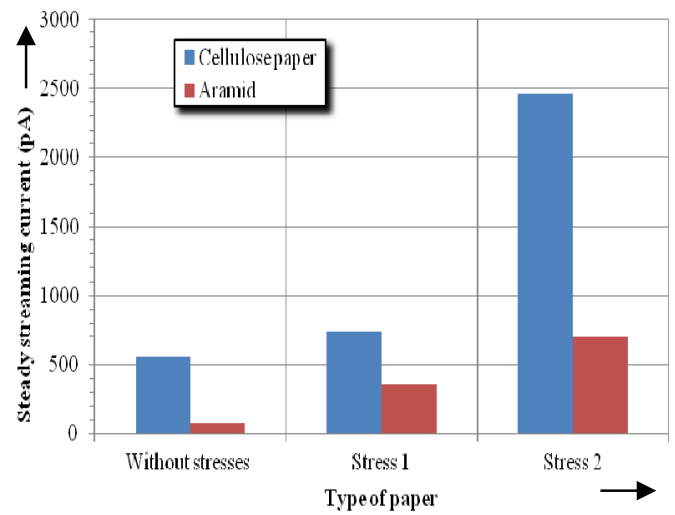

Fig. 14. Average streaming electrification current of the new oil for two type of paper. A $4 \mathrm{~cm}$ disc in diameter and $1 \mathrm{~mm}$ thick $=$ paper was considered. The rotational speed was set to $\mathrm{v}=600 \mathrm{rpm}$ while the Interfacial tension of the oil was 15.06 dynes $/ \mathrm{cm}$. 


\subsection{Influence of free radicals on the ECT}

The relative free radical content for the artificially aged oil was determined using the UV-vis spectrophotometric method. A free radical reagent, 2,2-diphenyl-1picrylhydrazyl (DPPH), is added to a solution of toluene and oil whose free radical concentration is to be determined. The rate that the DPPH disappears is directly proportional to the relative free radical content at a particular time. Solutions of DPPH, even at a concentration of $10^{-5} \mathrm{M}$, are blue-violet coloured. When the DPPH's free electron forms a doublet with the electron of another free radical, the colour of the solution changes from blue-violet to yellow, with a corresponding decrease in absorbance [54]. The larger the number of radicals in the oil, the faster it reaches zero absorbance. The scavenging activity of the DPPH can be represented by the following chemical reactions where $\mathrm{AH}$ denotes an anti-oxidant and $\mathrm{R}$ a free radical.

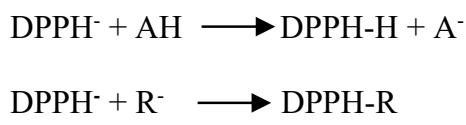

The DPPH is a stable free radical and its $0.01 \%$ solution gives constant absorbance of $0.500( \pm 0.005)$ at $520 \mathrm{~nm}$. A sweep between 500 and $540 \mathrm{~nm}$ was performed and, repeated every minute. Then, the area below the absorbance curve was computed for each sweep.

The results of these measurements are shown in Figures 15 and 16.

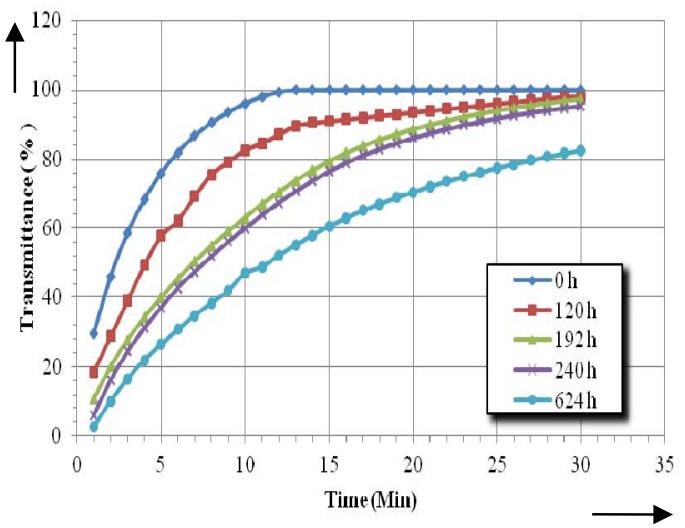

Fig. 15. The relative amount of free radicals as a function of time for artificially aged oil (samples aged with aramid papers).

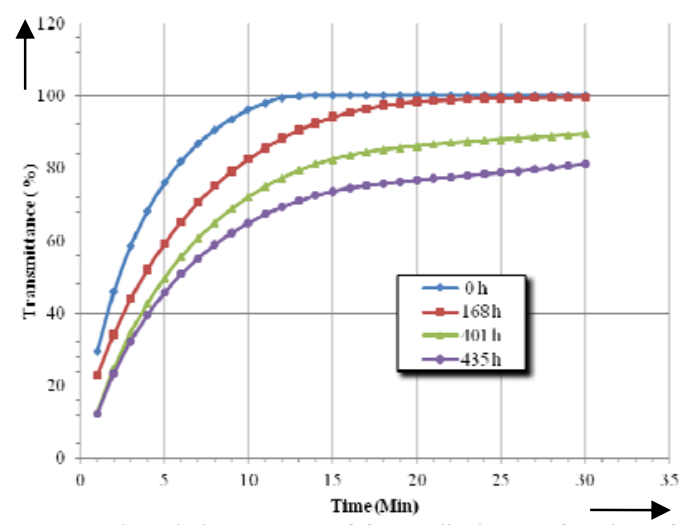

Fig. 16. The relative amount of free radicals as a function of time for artificially aged oil (samples aged with celullose papers).
Out of these figures, it can be seen that the relative amount of free radicals decreased as a function of the aging duration, contrary to the results reported by Loiselle et al. [43]. The main difference might be traced to the aging procedures. In these investigations, the oil samples have undergone artificial aging in the presence of paper, while the oil samples investigated by Loiselle et al. have undergone aging without paper. Decomposition products consist in gases, free radicals, ionized molecules and waxes that are the result of the degradation of the oil in service. The content of these decomposition products dissolved in the insulating oil consists of a decomposed variety, such as peroxides, aldehydes, ketones, and organic acids. These by-products may be adsorbed on the large surface of paper insulation leading to premature aging of transformers [29, 55]. The paper might have trapped a large quantity of aggressive free radicals. Field experiences related to static electrification reveal that breakdown is observed in the lower parts of the windings where there are large blocks of the pressboards [2]. This may be traced to radicals absorption. This is in agreement with studies carried out to improve the absorption characteristics of cellulose by cold plasmas that have shown that radicals formed under plasma cause chain degradation [56]. It is also reported that these radicals are responsible for the appearance of double bonds.

Figures 17, 18 and 19 illustrate the variation of the relative amount of free radicals as a function of time after electrical and thermal stress applications. Concomitant increase in the relative amount of free radicals is observed. The effect is more important for the thermal stress due to the involved energy.

Recall that the free (e-) electrons generated by a permanent electric discharge (five hours, stress 1) or by a transient electrical discharge (50 consecutive arcs - stress 2) break the hydrocarbon chains are responsible of oil degradation. The collisions between these accelerated free electrons and the hydrocarbon molecules can be elastic or inelastic depending on their mobility (velocity) [27].

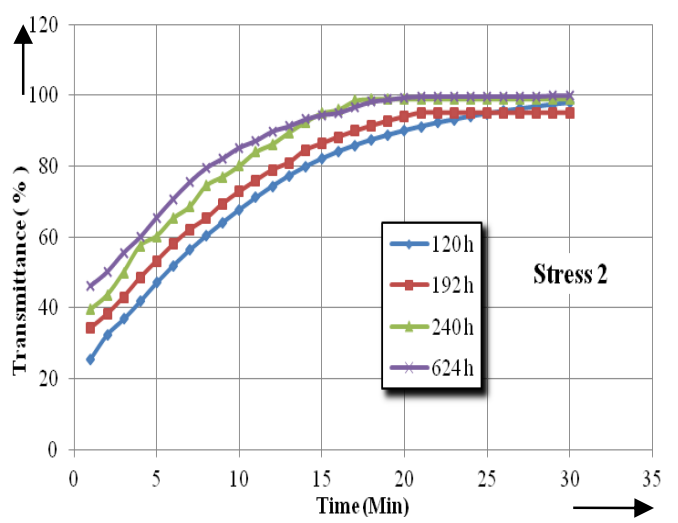

Fig. 17. The relative amount of free radicals as a function of time after the application of stress 2 (celullose paper). 


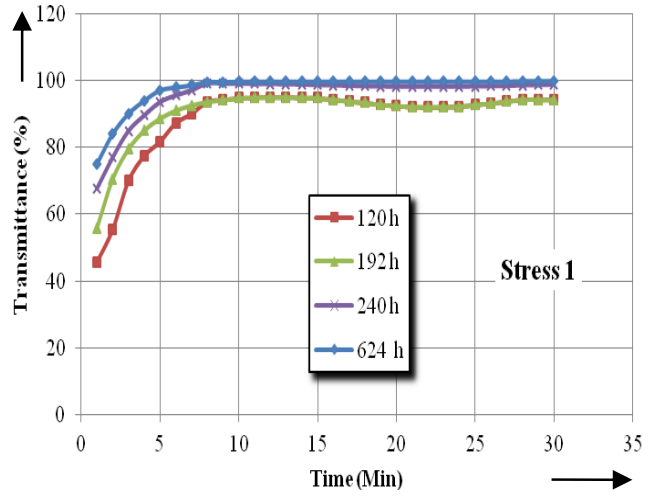

Fig. 18. The relative amount of free radicals as a function of time after the application of stress 1 (celullose paper)

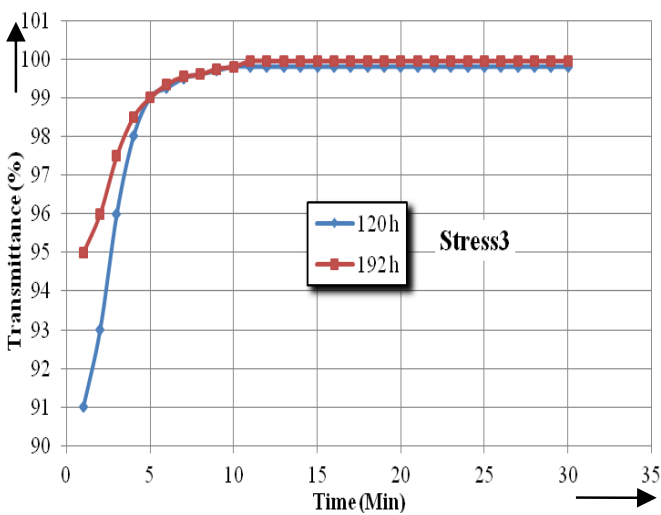

Fig. 19. The relative amount of free radicals as a function of time after the application of stress 3 (celullose paper).

\section{Conclusions}

In this contribution, experimental results onto the electrification current were reported as function of oil's aging condition. Various stresses (electrical and thermal) were considered and the relative amount of free radicals monitored in addition to the interfacial tension, dissolved decay products, turbidity and moisture content. The results obtained can be summarized as follow:

- The aging of oil increases the electrostatic charges and consequently the streaming electrification current.

- The chemical makeup and roughness of the paper insulation influences the electrification current generated at the oil / paper interface.

The degradation of the quality of the oil under the impact of the various stresses influences the electrostatic phenomenon. The phenomenon is more pronounced for the local overheating. In certain cases, the local thermal stress has caused polarity reversal. The theoretical premises that, free radicals contribute to the streaming electrification, is, experimentally confirmed under laboratory conditions. The reason that this information is important is that ECT can significantly affect partial discharge inception in in-service transformers.

\section{ACKNOWLEDGMENT}

This work is carried out within the Research Chair on Aging Power Network Infrastructure (ViAHT) at University of Quebec at Chicoutimi, as part of an exceptional national program (PNE) granted by Algerian government to finalize doctoral theses. Thanks are also extended to the institute of Maintenance and of Industrial
Security (IMSI), University of Oran 2 (Algeria) for supporting the research stay of Mrs Talhi in Canada.

\section{REFERENCES}

1. Deba Kumar, M. and Shakuntala, L.: Electrical insulating liquid. Journal of advanced dielectrics, ,vol.7(4), 9 pages, (July 2017).

2. Bourgeois, A.: Étude du phénomène d'électrisation par écoulement sur les cartons des transformateurs de puissance. Thèse de doctorat, Institut National Polytechnique, Grenoble, (9 Fevrier 2007), France.

3. Bourgeois, A., Paillat, T., Moreau, O. Mortha, G. and Touchard, G.: Flow electrification in power transformers: salt-type additive as a potential remedy?. Journal of Electrostatics, Vol. 63, 877-882, (2005).

4. Leblanc, P.: Etude du phénoméne d'electrisation par écoulement : Impact d'un champ électrique externe sur la Double Couche Electrique. Thése de doctorat, Science et Ingénierie en Matériaux, Mécanique, Energétique et Aéronautique, Université de Poitiers, (1er Décembre 2015), France.

5. Talhi, M., Fofana, I. and Flazi, S. : Impact of various stresses on the streaming electrification of transformer oil. Journal of Electrostatics, vol. 79, 25-32, (2016).

6. Leblanc, P., Paillat, T., Morin, G., and Perrier, C.: Behavior of the Charge Accumulation at the Pressboard/Oil Interface under DC External Electric Field Stress. IEEE.Transactions on Dielectrics and Electrical Insulation, Vol. 22(5), 2537-2542, (2015).

7. Metwally, I., Leblanc, P., Paillat, T.: Behavior of Electrical Double Layer under Oil Flow and Voltage Application inside a Capacitive Sensor. IET Science, Measurement \& Technology, SMT-20130179, (17 $7^{\text {th }}$ Sep 2013).

8. Metwally, I.: Characterization of static electrification in power transformers. IEEE Transactions Dielectric Electrical Insulations, vol. 3(2), 307-315, (1996).

9. Metwally, I., Leblanc, P., Paillat, T.: Measurement of currents and floating potential in multilayer sensor due to oil-flow electrification.Journal of Electrostatics, Vol. 71, 1061-1067 (décembre 2013).

10. Talhi, M., Fofana, I. and Flazi, S. :Comparative Study of the Electrostatic Charging Tendency between Synthetic Ester and Mineral Oil. IEEE Transactions Dielectric Electrical Insulations, Vol. 20 (5), 1598-1606, (October 2013).

11. Paillat, T., Onic, L., Moreau, O., Bertrand, Y., Mortha, G., Charvet, N., and Touchard, G.: Influence of Pressboard Physico-Chemical Composition on Static Electrification in Power Transformers. IEEE Transactions Dielectric Electrical Insulations, Vol. 39, 346-354, (2003).

12. Kedzia, J., Investigation of transformer oil electrification in a spinning disc system, IEEE Transactions Dielectric Electrical Insulations, Vol. 24 (1), 59-65,(1989).

13. Félici, T. J., Gosse, J. P. and Slofomboahany, A.: Liquid Flow Electrification and Zeta-potential in Hydrocarbons. Journal of Electrostatics, Vol. 12, 369-376, (1982).

14. N'Cho, J. S., Fofana, I., Aka-Ngnui, T. and Beroual, A.: Parameters Affecting the Static electrification of aged transformer Oils. Annual Conference on Electrical Insulation and Dielectric Phenomena (CEIDP), Cancun, Mexico, (16-19 Oct 2011).

15. El-Adawy, M., Paillat, T., Bertrand, Y., Moreau, O., and Touchard, G.: Physicochemical analysis at the interface between conductive solid and dielectric liquid for flow electrification phenomenon. IEEE Transactions Dielectric Electrical Insulations, Vol. 46(4), $1593-1600,(2010)$

16. Fofana, I., Bouslimi, Y., Hemmatjou, H., Volat, C., Tahiri, K.: Relationship between static electrification of transformer oils with turbidity and spectrophotometry measurements. Electrical Power and Energy Systems, Vol. 54, 38-44, (2014).

17. Peyraque, L., Béroual, A., and Buret, F.: Static electrification of pressboard/oil interface and transient phenomena. IEEE Transactions Dielectric Electrical Insulations,vol. 5 ( 3), 443-448 (June 1998).

18. Crofts, D.W.: The Static Electrification Phenomena in Power Transformers. IEEE Transactions Dielectric Electrical Insulations, Vol. 23 ( 1), (1988).

19. Oommen, T. V. and Lindgren, S. R: Static electrification properties of transformers oil. IEEE Transactions Dielectric Electrical Insulations ,Vol. 23 (1), 123-128, (1998).

20. Zmarzly, D.: Streaming electrification measurements in swinging cylinder system. IEEE Transactions Dielectric Electrical Insulations, BVol. 19 (5), 1665 - 1672, (2012) 
21. Zelu, Y., Paillat, T., Morin, G., Perrier, C., Saravolac, M.: Study on flow electrification hazards with ester oils . 2011 IEEE International Conference on Dielectric Liquids (ICDL), Trondheim, Norway, (26-30 June, 2011).

22. Shuangzan, R., Qiang, L., Lisheng, Z., Qinxue, Y., Yang X. Xiaolong, C., Masahiro, H., Shin, Y., and Shigekazu. M.: Electrostatic charging tendency and correlation analysis of mineral insulation oils under thermal aging. IEEE Transactions Dielectric Electrical Insulations, Vol.18( 2), 499 - 515, (April 2011).

23. Poovamma, K., Jagadish, P. K.: Dwarakanath, R., Investigation on static electrification characteristics of transformer oil. Journal of Electrostatics, Vol.33(1), 1-14, (1994).

24. Klinkenberg, A. and Van Der Minne, J. L.: Electrostatics in petroleum industry. Elsevier Publishing Company, pp.191, (1957).

25. Nelson, J. K. and Lee, M. J.: Electrokinetic effects in power transformers. Rap. tech.EL/ER 6880, EPRI, (1990).

26. Briosso, E., Fofana, I., Robertson, B. and Sabau, J.: Enhancing the Maintenance of Transformer Oils to Diminish the Risk of Blackouts, Energetica.vol.55,465-469. December 2007.

27. Fofana, I., Bouaïcha, A., Farzaneh, M., Volat, C., and Sabau, J.:On the Stability of Mineral Insulating Oils under Electrical Stress. The 2009 IEEE Electrical Insulation Conference, Montréal, June 2009

28. Tanaka, J.: Free Radicals in Electrical Insulation .19 ${ }^{\text {th }}$ Symposium of Electrical Insulating Materials, Osaka, Japan (1986).

29. N'Cho, J.S.: Developpement de nouvelles methodes de diagnostic et de regeneration des huiles pour transformateurs de puissance. Thése de doctorat, École doctorale électronique, électrotechnique, Automatique, Lyon, France (10 mars 2011).

30. Sabau, J.: Fast Photochemical Oxidation Procedure of Uninhibited Insulating Oils. Energetica, Vol. 23, 9-10, (1975).

31. Samat, J.: Summary of the TF activity since. 1990 CIGRE Session, 1990, Report CIGRE SC 15 WG 15-01.

32. Group, C.J.W.: Static Electrification in Power Transformers. in CIGRE 1992 General Session, paper 15/12-03, Paris.

33. Harvey, T. J., Wood, R. J. K. Denuault, G. Powrie, H. E. G.: Effect of oil quality on electrostatic charge generation and transport. Journal of Electrostatics, Vol. 55(1), 1-23, (2002).

34. Kędzia, J., Willner, B.: Electrification Current in the Spinning Disc System. IEEE Transactions Dielectric Electrical Insulations. Vol 1, 58-62, (1994).

35. Zdanowski, M., Wolmy, S., Oktawian, D. and Boczar, T. Electrostatic Charging Tendency of ethanol and hexane mixtures in the spinning disk system, Journal of Electrostatics, Vol 65(4), 239243, (2007)

36. Poovamma, K., Jagadish, P. K., Dwarakanath, R.: Investigation on static electrification characteristics of transformer oil. Journal of Electrostatics, Vol. 33, 1-14, (1994).

37. Bard, A. J., Faulkner, L. R.: Electrochemical Methods: Fundamentals and Applications. Wiley, London, 500-502, (1980).

38. Peyraque, L., Bleroual, A., Buret, F.: Static electrification of pressboard/oil interface and transient phenomena, oils. IEEE Transactions on Dielectric Electrical Insulation, Vol. 5 (3), 443448, (1998)

39. ASTM D 1934-95:Standard Test Method for Oxidative Aging of Electrical Insulating Petroleum Oils by Open-Beaker Method. Annual Book of ASTM standards, 1-3, (2004).

40. ASTM D 6180:Standard Test Method for stability of Insulating Oils of Petroleum Origin under Electrical Discharges. Annual Book of ASTM standards, Vol. 10.03, (2008)

41. ASTM D 877: Standard Test Method for Dielectric breakdown Voltage of Insulating liquides Using Disk Electrodes. Annual Book of ASTM standards, Vol. 10.03,(2008).

42. Jovalekic, M., Vukovic, D. and Tenbohlen, S.: Dissolved gas analysis of alternative dielectric fluids under thermal and electrical stress. IEEE International Conference on Dielectric Liquids (ICDL), Trondheim, Norway, (26-30 juin 2011).

43. Loiselle, L., Fofana, I. and Sabau, J.: Influence of Ageing byproducts on the Stability of some Transformer Fluids, 2012 CIGRE Canada Annual Conference,Montréal, Québec, (September 24-26 2012)

44. ASTM D 1533: Standard Test Method for Water in insulating liquids by Coulometric Karl fisher Titration. Annual Book of ASTM standards, Vol. 10.03,(2005).

45. ASTM D 6181: Standard Test Method for Measurement of Turbidity in Mineral Insulating Oil of Petroleum Origin. Annual Book of ASTM standards, Vol. 10.03, (2003).

46. ASTM D 971, Standard Test Method for Interfacial Tension of oil against water by the ring method, in Annual Book of ASTM standards, Vol.10.03, (2004).
47. ASTM D 6802-02, Test Method for Determination of the Relative Content of Dissolved Decay Products in Mineral Insulating Oils by Spectrophotometry, in Annual Book of ASTM standards, Vol. 10.03.(2002).

48. Fofana, I., Sabau, J. and Betie, A.: Measurement of the Relative Free Radical Content of Insulating Oils of Petroleum Origin. Energies, Vol. 8(8), 7690, (2015).

49. Gumilang, H.: Unique Relationship between Interfacial Tension (IFT) and Neutral Number Test (Acidity) of Transformer Insulation Oil in PLN P3B JB Jakarta and Banten Regional. IEEE $9^{\text {th }}$ International Conference on the Properties and Applications of Dielectric Materials, Harbin, China, (July 19-23, 2009).

50. Perrier, C. and Beroual, A.: Experimental Investigations on Insulating Liquids for Power Transformers: Mineral, Ester, and Silicone Oils. IEEE Electrical Insulation Magazine, $6-13$, November/December 2009

51. Zouaghi, A.: Etude de l'influence des barrières isolantes sur la tenue diélectrique d'intervalles d'huile en chocs de foudre et en continu. Thèse de Doctorat, École Centrale de Lyon, (1997).

52. Tran Duy, C., Denat, A., Lesaint, O., Bonifaci, N., Bertrand, Y., Daound, W. and Hassanzadeh, M.: Influence of ageing on conduction and breakdown in rape-seed and mineral oils. International Conference on Dielectric Liquids, ICDL, Poitiers, France (2008)

53. Touchard, G., Flow electrification of liquids. Journal of Electrostatics, Vol. 51-52, 440-447. (2001).

54. Sabau, J. and Stokhuyzen, R.: The Electrochemical Stability of Mineral Insulating Oils. Electrical Insulating Materials, International Issues, ASTM STP 1376, M. M. Hirschler. American Society of Testing and Materials, West Conshohocken, PA, (2000).

55. Bouaïcha, A.: Contribution à l'application de techniques traditionnelles et modernes au diagnostic des transformateurs de puissance. Thése de doctorat, Université du Québec à Chicoutimi, Canada (Septembre 2014).

56. Roux, J. L.: Modification des fibres cellulosiques amelioration des proprietes hydrophiles des pates bisulfites. Thèse de doctorat, Université de Bordeaux 1, École doctorale des sciences chimiques, France (14 mars 2003). 